\title{
Factors Affecting OFDI in Indian Manufacturing Firms: Technical Analysis
}

\author{
Juhi Lohani, Timsi Bhatia \\ *Corresponding Author: Juhi Lohani
}

Received Date: 12-04-2017

Accepted Date: 28-04-2017

Published Date: 12-04-2017

\begin{abstract}
This study focuses on factors affecting Outward Foreign Direct Investment of firms in the manufacturing sector of India. The period of the study is 2008-2010.The aim of the study is to analyze whether Research and Development has a positive impact on OFDI intensity. It shows that in the current years the results have changed. Firms manufacture abroad and then import the goods into India.
\end{abstract}

\section{INTRODUCTION}

For the last few years it has been observed that in India inflow of FDI is declining whereas Outflow of investment to other countries has been increasing. The problems in attracting FDI are reflected in international comparisons of the investment climate. In the World Bank Doing Business Report 2012, India is ranked 132 out of 183 countries. In addition to this, according to Global competitive Index (2012-13) which measures the set of institutions, policies and other factors that affects the business environment of a country published by World Economic Forum, India has been ranked $59^{\text {th }}$ out of 144 countries. India's rank is poorer as compared to China $\left(30^{\text {th }}\right)$ and other ASEAN countries like Singapore $\left(2^{\text {nd }}\right)$, Malaysia $\left(25^{\text {th }}\right)$, Thailand $\left(38^{\text {th }}\right)$ and Indonesia $\left(50^{\text {th }}\right)$. The reasons behind India's disappointing performance and failure to attract global investment are insufficient and ill-adapted infrastructure, and institutional problems like corruption and bureaucracy. Due to these reasons many Small and Medium Indian enterprises particularly in the manufacturing sector are investing in the ASEAN countries as the infrastructure available in those countries, reduces the cost of production to a great extent.

Apart from these reasons there are several other factors that push a firm to invest in other countries. One of the major reasons is poor investment climate in home country.

\section{LITERATURE REVIEW}

Review of literatures available on OFDI reveals Indian firms are investing abroad to access foreign markets, production facilities and international brand names. For example: Tata Tea acquired Tetley Tea to access the Tetley brand name and market. Access to technology and knowledge has been a strategic consideration for Indian firms, for example; in 2003, WIPRO acquired Nerve Wire Inc (USA) to secure deep domain knowledge and other IT related benefits, including access to markets. Reliance Infocomm paid money for Flag Telecom (United Kingdom) to access to the undersea cable network and connect with key regions such as Asia, Europe and the USA. A number of such motives including access to foreign technology, sourcing of raw materials aspirations for global leadership or due to institutional and policy voids in the home country. Firms also try to take advantage of double taxation avoidance implemented by some countries.

However, the motive for investing abroad depends on the size of the firm. Large size firms might have different reasons to invest in other countries as compared to Small and Medium size firms. This has been proved by Hollenstein (2005) in his study on "Determinants of International Activities: Are SME's Different?" which confirms, Dunning's well-known OLI paradigm. Ownership advantages turn out to be 
the main drivers of internalisation, irrespective of firm size and internalisation strategy. However, the knowledge base on which Ownership advantages of small firms rests is narrower than that of large companies. Whereas the small firms rely, in relative terms, primarily on capabilities related to incremental innovations, the large firms draw to a higher extent on assets enabling them to be competitive in terms of far reaching innovations. Location advantages like wages, regulatory framework and infrastructure primarily are relevant in case of small firms as compared to large firms.

The data for analysis has been taken from RBI, which gave the total amount invested by firms in other countries. The time period of my study is from 2008 to 2010. This period also witnessed a global slowdown in the world economy, due to the recession of 2008. The firm level data for analysis has been taken from Prowess, which is a database of the financial performance of Indian companies and also provides data on foreign equity and exports of companies providing us with a measure of outward FDI. There are around 11,000 manufacturing firms in India, but for this particular analysis data coverage is from 2008-2010 resulting in 277 firms to be analyzed. It is an unbalanced panel data with 88,89 and 100 companies investing abroad in the year 2008, 2009 and 2010 respectively. Since the data set is a panel data, the advantage of using panel data is that it controls the effects of missing or unobserved information. Our data has the problem of Hetroskedecity, which has been detected by using Breusch Pagan Test. Hence robust estimates are being used. To choose between fixed effect and Random effect Hausman test is conducted and fixed effect results are chosen on the basis of this test.

\section{ANALYSIS OF DATA}

The dependent variable is the ratio of OFDI amount by a firm to the sales of the firm.

\section{OFDI/SALES $=\mathbf{X}_{\mathrm{it}} \mathbf{B}+\mathbf{u}_{\mathrm{it}}$}

$X_{i t}$ is a vector of determinants that affect OFDI/Sales explaining the $i$ th firm's overseas investment decision in the $t$ th time period. The firm level heterogeneity can be studied by taking into account various explanatory variables and the fixed effect results obtained are as follows:
Table6.1. Fixed Effect Results

\begin{tabular}{|l|l|}
\hline Independent variable & Coefficient \\
\hline Age & -0.062 \\
& $(0.250)$ \\
\hline Age $^{2}$ & $0.001^{* *}$ \\
& $(0.031)$ \\
\hline R\&D & $0.011^{* * *}$ \\
& $(0.006)$ \\
\hline Profit after tax & $-22.58^{* * *}$ \\
& $(0.006)$ \\
\hline Exports & $-225.238^{* *}$ \\
& $(0.011)$ \\
\hline Imports & $452450.5^{* *}$ \\
& $(0.011)$ \\
\hline Size & $-0.1407^{* * *}$ \\
& $(0.000)$ \\
\hline Ads & $-0.0002^{* *}$ \\
& $(0.040)$ \\
\hline Constant & 1.47 \\
& $(0.103)$ \\
\hline R square & 0.13 \\
\hline *** Significant at 1\%,**Significant at 5\%, \\
*Significant at 10\%
\end{tabular}

Table representing the value of coefficient and the values in the bracket represent the p-value of the variable.

The results obtained in this study are not similar to the expected results and are in contrast with the results of previous studies.

According to the present study the variable capturing the impact of Research and Development intensity of an enterprise, $R \& D$, which results in innovation of new products and methods has a positive impact on OFDI intensity. The firms having considerable expenditure on Research and Development activities are more likely to invest in other countries.

The variable EXPORTS, capturing the Export intensity of a firm in the present study is negatively related to OFDI. According to the product cycle theory of Vernon (1966), overseas investment is postulated to follow the initial exploration of overseas markets through exporting. It has been argued that the recent boom of overseas investment by developing country enterprises has been motivated by the need to support exporting with a local presence (Kumar, 1998). Exporting activity enhances the international competitiveness of the enterprise and may also provide valuable information on emerging opportunities in other countries. 
Hence, the export intensity (EXPORTS) of Indian enterprises is posited to be positively linked to the probability of establishing overseas operations. (Kumar, 2007)

However, these results are based on a sample for earlier years. In the current sample period the relationship seem to have changed from positive to negative. It means that OFDI is undertaken not to promote exports in India. On the other hand Indian firms invest abroad as it is more efficient to produce the good abroad and import back to India. Clearly, in the Manufacturing sector of India, export does not increase OFDI.

Next is IMPORTS representing the import intensity of a firm, has unusually high coefficient and is positively related to OFDI in the manufacturing sector, which means that firms are importing back the goods to India produced in other countries, probably producing in their own subsidiaries located in other countries and importing back those goods in India.

SIZE, representing the Sales of a firm, is also negatively related to OFDI intensity which shows that in the manufacturing sector of India even the small and medium sized firms are investing abroad not only the large firms. Firms of all sizes are exploring options outside to get access to advantages offered by other countries. It is not just Tata's, Birla's or Ambani's anymore.

The variable PAT, capturing the effect of Profit after Tax on OFDI decision taken by a firm is also negative, which means that, smaller profit firms are indulging more in OFDI rather than large profit firms. This is also supported by the variable $\mathrm{AGE}$ and $\mathrm{AGE}^{2}$, since only $\mathrm{Age}^{2}$ is significant implying that mainly the SME's are investing abroad.

Advertisement intensity captured by ADS, measures product differentiation, it is significant and has a negative impact on OFDI, this is because the firms indulged in FDI outflows are producing standardized products as they are Small and Medium firms. So advertisement intensity does not increase OFDI based on brand names in the global market.

Further, Logit model has been estimated taking dependent variable .i.e. OFDI intensity equal to 1 if OFDI intensity is greater than $\$ 0.05$ million, than from our sample of 277 firms, 166 firms has OFDI intensity greater than $\$ 0.05$ million. The results are similar to the above results apart from the variable $\mathrm{Age}^{2}$ which turned out to be insignificant in this case.
Another Logit model that has been estimated in which OFDI is taken as 1 if OFDI intensity is greater than $\$ 0.5$ million; in this case 27 firms are investing more than $\$ 0.5$ million. The results show that only size is not significant for these firms. The results for the Logit model are as follows:

\section{Logit Model Results}

\begin{tabular}{|l|l|l|}
\hline $\begin{array}{l}\text { Independe } \\
\text { nt } \\
\text { variables }\end{array}$ & $\begin{array}{l}\text { Dependent } \\
\text { Variable } \\
\text { OFDI } \\
\text { (intensity) } \\
\text { 1 if OFDI>0.05; } \\
\text { 0 otherwise }\end{array}$ & $\begin{array}{l}\text { Dependent } \\
\text { Variable } \\
\text { OFDI } \\
\text { (intensity) } \\
\text { 1 if OFDI }>\mathbf{0 . 5} \text {; } \\
\text { 0 otherwise }\end{array}$ \\
\hline Age & $\begin{array}{l}-0.002 \\
(0.981)\end{array}$ & $\begin{array}{l}-0.07 \\
(0.143)\end{array}$ \\
\hline Age ${ }^{2}$ & 0.0016 & $0.001^{* *}$ \\
& $(0.342)$ & $(0.015)$ \\
\hline R\&D & $0.025^{* *}$ & $0.012^{* *}$ \\
& $(0.020)$ & $(0.049)$ \\
\hline PAT & $-49.59^{* *}$ & $-23.94 * *$ \\
& $(0.020)$ & $(0.049)$ \\
\hline Exports & $-580.94^{* *}$ & $-200^{* *}$ \\
& $(0.028)$ & $(0.056)$ \\
\hline Imports & $1167472^{* *}$ & $401709.3 * *$ \\
& $(0.028)$ & $(0.057)$ \\
\hline Size & $-0.371^{* * *}$ & -8.96 \\
& $(0.001)$ & $(0.167)$ \\
\hline Ads & $-0.001^{* * *}$ & $0.018^{* *}$ \\
& $(0.000)$ & $(0.747)$ \\
\hline Constant & 1.40 & 0.45 \\
& $(0.118)$ & $(0.583)$ \\
\hline R square & 15.54 & 0.0990 \\
\hline No. of & 166 & 27 \\
firms with & & \\
value 1 & & \\
\hline$* * * 5 i g n i f i c a n t$ & \\
\hline
\end{tabular}

*** Significant at $1 \%$,**Significant at $5 \%$, *Significant at $10 \%$

Table representing the value of coefficient and the values in the bracket represent the

p-value of the variable.

\section{Random Effect Results}

The dependent variable is the ratio of OFDI amount by a firm to the sales of the firm.

\begin{tabular}{|l|l|}
\hline Independent variable & Coefficient \\
\hline Age & -0.00027 \\
\hline Age $^{2}$ & $3.83 \mathrm{e}-06$ \\
\hline R\&D & 0.000887 \\
\hline Profit after tax & -0.174 \\
\hline Exports & -0.00028 \\
\hline Imports & -1.5193 \\
\hline Size & -0.0022 \\
\hline Ads & -0.09211 \\
\hline Constant & 0.031 \\
\hline R square & 0.08 \\
\hline
\end{tabular}

No variable is significant in the Random effect model. 


\section{CONCLUSION}

The key lesson emerging from the above analysis is that it is more efficient to manufacture goods in the host country because of good quality physical infrastructure like transportation, telecommunication, electricity which are extremely important for competent production of goods. OFDI in manufacturing sector has become a serious issue because of infrastructural problems in India. It has become cheaper for firms to produce outside India and import back rather than manufacturing in their own country. This is because of poor physical and institutional infrastructure in India which acts as a push factor for OFDI of small and medium firms. In addition to this the investment climate that can be explained by the performance of individual states in terms of investment and growth in India has deteriorated. Institutional and physical infrastructure appears to be the most important constraint, as it is particularly binding in states that show low levels of domestic investment and GDP growth. Appropriate institutional infrastructure like absence of corruption, legal dispute settlement and rule of law are very important for improving the business investment climate in a country. The larger firms can set up electricity generation plants which increases the cost of production because they can afford to bear this cost but small and medium firms cannot do this, so they are opting to produce outside. So, the conclusion is that small and medium enterprises in the manufacturing sector are producing abroad and importing back the goods in India.

\section{REFERENCES}

[1] Pradhan, J. P. (2010). Group Affiliation and Location of Indian Firm's Foreign Acquisition. Munich Personal RePEc Archive, 25.

[2] Kumar, N. (2007). Emerging TNC'S:Trends, Patterns and determinants of Outward FDI by Indian Enterprise. Transnational Corporations , 26.

[3] Bhaumik, S. K., Driffield, N., \& Pal, S. (2009). Does Ownership structure of Emerging market firms affect their Outward FDI? The case of Indian automotive and Pharmaceutical sector. Journal of International Business Studies .

[4] Subramaniam, R., Sachdeva, C., \& Morris, S. (2010). FDI Outflows from India: An estimation of the underlying Economics, Policies and their impact. IIMA , 96.

[5] Hattari, R., \& Rajan, S. (n.d.). India as a source of Outward Foreign Direct Investment. Oxford Development Studies .

[6] Hollenstein. (2005). Determinants of international activities: Are SMEs different?

[7] Siddharthan, N. (2009). Foreign Direct Investment: Main Determinants.

[8] Pradhan. (2007). INDIAN MULTINATIONALS in the world economy, Implications for development. Academic Foundation.

[9] Singh, N. Technological Efforts and Global Operations: Indian Auto Component Firms.

[10] Rao, K. C., \& Dhar, B. (2011). India's FDI inflows Trends and Concepts

Citation: Juhi, Lohani, and Bhatia Timsi. "Factors Affecting OFDI in Indian Manufacturing Firms: Technical Analysis." International Journal of Research in Humanities and Social Studies, vol 4, no. 4, 2017, pp. 9-12.

Copyright: (C) 2017 Juhi, Lohani, et al. This is an open-access article distributed under the terms of the Creative Commons Attribution License, which permits unrestricted use, distribution, and reproduction in any medium, provided the original author and source are credited. 